\title{
Potential role of vitamin D receptor-related polymorphisms in bronchopulmonary dysplasia
}

\author{
Walaa Alsharany Abuelhamd', Nancy Abdel Salam Gomaa', Alaa Gad ${ }^{2,3^{*}}$ (D) and Rehab El-Wakeel ${ }^{2}$
}

\begin{abstract}
Background: The potential contribution of vitamin D and its receptor (VDR) to bronchopulmonary dysplasia (BPD) in preterm neonates is still unknown. The objective of the study was to test the relationship between VDR Taq 1 and Fok 1 gene polymorphisms and BPD in preterm neonates. VDR Fok 1 and Taq 1 gene polymorphisms were genotyped by polymerase chain reaction-restriction fragment length polymorphism (PCR-RFLP) analysis.

Result: No statistically significant differences of genotypic distributions and allele frequencies of Fok 1 and Taq 1 VDR polymorphisms were detected between cases and controls. Moreover, no risk association was detected between both polymorphisms and BPD development in preterm neonates. Homozygous mutant (ff) genotype was the least frequent genotype among BPD and non-BPD groups $(2.6 \%, 13.0 \%$ respectively) $(p=0.1)$. The same was detected for the mutant (CC) genotype frequency in both groups (10.5\% and 15.2\%, respectively). However, Taq 1 VDR polymorphism was significantly associated with the severity of BPD, as the genotypes with mutant allele C (CC $+C T$ ) were more frequent among severe cases (52.2\%).
\end{abstract}

Conclusion: Fok 1and Taq 1 VDR polymorphisms have no role in BPD development in preterm neonates. However, the presence of a mutant allele of Taq 1 VDR polymorphism may be associated with a more severe form of the disease.

Keywords: Bronchopulmonary dysplasia, Polymorphism, Premature neonates, Vitamin D receptor

\section{Background}

Bronchopulmonary dysplasia (BPD) is a worldwide major challenging consequence of prematurity and has a significant heritability [1]. In the USA alone, yearly reported new cases were about $10,000-15,000$ [2]. Moreover, another study reported that BPD incidence ranged from $20 \%$ in preterm infants up to $60 \%$ in extremely preterm infants who were born before 26 weeks of gestation [3]. Although the major inflammatory role in the pathogenesis of BPD due to prematurity and perinatal triggering factors has been

\footnotetext{
* Correspondence: aag0121@my.londonmet.ac.uk

${ }^{2}$ Department of Clinical and Chemical Pathology, Cairo University, Cairo, Egypt

${ }^{3}$ Cairo, Egypt

Full list of author information is available at the end of the article
}

established, the genetic predisposition mechanisms remain unknown $[4,5]$. According to twin studies, molecular factors represent about $53-82 \%$ of the variance in predisposition to BPD [6,7]. Bronchopulmonary dysplasia is associated with future risk of reactive airway disease [3], infant mortality, and conflicting neurodevelopmental outcomes [8]. There are limited therapies available to prevent BPD despite recent advances, hence comes the role of genetic variants [2].

The effect of vitamin D on bone and mineral metabolism has been well-known through the role of the vitamin $\mathrm{D}$ receptor (VDR) that acts as a ligand-activated transcription factor [9].

The VDR is expressed in numerous systems other than skeletal, such as immune and respiratory systems [10].

\section{Springer Open}

(c) The Author(s). 2021 Open Access This article is licensed under a Creative Commons Attribution 4.0 International License, which permits use, sharing, adaptation, distribution and reproduction in any medium or format, as long as you give appropriate credit to the original author(s) and the source, provide a link to the Creative Commons licence, and indicate if changes were made. The images or other third party material in this article are included in the article's Creative Commons licence, unless indicated otherwise in a credit line to the material. If material is not included in the article's Creative Commons licence and your intended use is not permitted by statutory regulation or exceeds the permitted use, you will need to obtain permission directly from the copyright holder. To view a copy of this licence, visit http://creativecommons.org/licenses/by/4.0/. 
The effect of vitamin D on several morbidities, such as multiple sclerosis, diabetes, and malignancies, has been established through affecting immunity and cell proliferation [11].

Several researchers reported the important role of vitamin D and its receptor in the pathogenesis of chronic lung diseases through interactions between genes related to cellular proliferation, differentiation, inflammation, and immunity [12]. Furthermore, some studies reported its important role as a regulator for intrauterine lung development [13-15]. In animal studies, a low level of vitamin $D$ with pregnancy tends to modify alveolar epithelial-mesenchymal signaling and reduce tracheal width, thus increasing airway resistance and reducing lung compliance, which results in lung hypofunction in fetal mice [16]. Additionally, in human studies, the impact of vitamin $\mathrm{D}$ on the production of pulmonary surfactant has been confirmed [17]. As it has an important role as a growth factor for type-II alveolar pneumocytes, local elaboration of VDR was considered an innovative mechanism that may affect the epithelial growth of lung development and modulation [18]. So, further studies are still needed to assess the relationship between VDR polymorphisms and BPD.

The aim of this study was to determine the possible association between VDR Fok 1 and Taq 1 gene polymorphisms and BPD susceptibility in Egyptian preterm neonates.

\section{Methods}

\section{Subjects}

This case-control study included 84 newborns and was carried out at the neonatal intensive care unit (NICU) of Kasr AlAiny Hospitals, Cairo University, over a period of 1 year, starting from December 2018 to November 2019.

Infants were recruited into the study if they had been admitted to NICU and born prematurely with a gestational age of $\leq 32$ weeks and a birth weight of $\leq 1500 \mathrm{~g}$. Newborns who fulfilled the criteria for the BPD diagnosis joined the case group (38 cases), while the matched control group (46 cases) was selected among premature cases that had been admitted to NICU for different purposes but did not fulfill the criteria for the diagnosis of BPD. A BPD diagnosis and severity were carried out depending on the National Institute of Child Health and Human Development (NICHD) severity-based definition of BPD [19]. For those born at less than 32 weeks of gestation, BPD was defined as the need for oxygen support of more than $21 \%$ for at least 28 days and a subsequent assessment at 36 weeks postmenstrual age or discharge. In the case of those born with more than 32 weeks of gestation, BPD was defined as the need for supplemental oxygen of more than $21 \%$ for at least 28 days and a subsequent assessment at 56 days postnatal age or discharge. At the time of assessment, infants with no oxygen need were considered as mild BPD. Moderate BPD was considered in cases needing less than $30 \%$ oxygen, while severe BPD was considered in cases with a need for positive pressure and/or oxygen support of $\geq 30 \%$ [19]. BPD risk factor-related data were collected from medical records of both groups: gestational age, birth weight, gender, mode of delivery, duration of mechanical ventilation, duration of oxygen therapy, administration of surfactant, presence of patent ductus arteriosus requiring treatment, duration of hospitalization, and mortality. Additionally, some prematurity-related complications were taken into account. They included respiratory distress syndrome (RDS) that was considered in premature infants when they presented shortly after birth with clinical signs of respiratory distress with the need for supplemental oxygen $\left(\mathrm{FiO}_{2}>0.21\right)$ to achieve oxygen saturation $>90 \%$ and evidence of respiratory acidemia in blood gasses $\left(\mathrm{pH}<7.25\right.$ and $\mathrm{PCO}_{2}>60$ $\mathrm{mmHg}$ ) [20].

The typical radiological findings and grading of RDS were considered in the chest $\mathrm{x}$-ray of all cases: hypoexpansion and diffuse fine granular appearance (grade I), air bronchogram caused by atelectasis of the alveoli (grade II), ground-glass opacities (grade III), or white lungs caused by diffuse bilateral atelectasis (grade IV) [21]. Sepsis was diagnosed by a positive blood culture or a positive C-reactive protein and the immature-to-totalneutrophil ratio of more than 0.2 with concomitant clinical signs of sepsis. Sepsis in the first three postnatal days was defined as early-onset sepsis (EOS), while later sepsis was defined as late-onset sepsis (LOS) [22]. Necrotizing enterocolitis (NEC) was detected based on modified Bell staging criteria [23], and cases with grade Ib or more were considered. Intraventricular hemorrhage (IVH) was diagnosed by cranial ultrasound, and we only considered cases with grade II or more.

All newborns suspected of having genetic diseases or congenital anomalies were excluded from both groups. The study protocol was approved by the Ethics Committee of Faculty of Medicine, and it conformed to the provisions of the Declaration of Helsinki of 1964 and its later amendments or comparable ethical standards. An informed written consent was obtained from parents/ surrogates of each child before enrollment in this study.

\section{Methods \\ Detection of vitamin $D$ receptor polymorphism using polymerase chain reaction-restriction fragment length polymorphism (PCR-RFLP)}

Genomic DNA of included subjects was isolated from ethylenediaminetetraacetic acid (EDTA)-treated whole blood, using a G-spin TM total DNA extraction kit 
(iNtRON Biotechnology, Korea). Genotyping of vitamin D receptor polymorphism (Fok1 and Taq1 sites) was performed using the PCR-RFLP technique. The primer sequences used were as follows: for Fok 1 polymorphism, forward primer: 5'-AGCTGGCCCTGGCACTGACTCT GCTCT-3', reverse primer: 5'ATGGAAACACCTTGCTTCTTCTCCCTC-3' [24], while for the Taq1 polymorphism, forward primer: 5'-CAG AGC ATG GAC AGG GAG CAAG-3', reverse primer: 5'GCAACT CCTCATGGCTGAGGTCTCA-3' [25]. Amplification was done using 2X PCR Master mix Solution (iTaqTM) (iNtRON biotechnology, Korea) in a total volume of $20 \mu l$.

For Fok 1 polymorphism amplification, an initial denaturation at $95{ }^{\circ} \mathrm{C}$ for $3 \mathrm{~min}$ was followed by 35 cycles consisting of $30 \mathrm{~s}$ of denaturation at $94{ }^{\circ} \mathrm{C}$, $30 \mathrm{~s}$ of annealing at $60{ }^{\circ} \mathrm{C}$, and an extension for 30 $\mathrm{s}$ at $72{ }^{\circ} \mathrm{C}$, and then, a final extension at $72{ }^{\circ} \mathrm{C}$ for 5 min. For Taq 1 polymorphism amplification, an initial denaturation at $95{ }^{\circ} \mathrm{C}$ for 3 min was followed by 35 cycles consisting of $45 \mathrm{~s}$ of denaturation at 93 ${ }^{\circ} \mathrm{C}$, $30 \mathrm{~s}$ of annealing at $66{ }^{\circ} \mathrm{C}$, and an extension for $45 \mathrm{~s}$ at $72{ }^{\circ} \mathrm{C}$ and then a final extension at $72{ }^{\circ} \mathrm{C}$ for $5 \mathrm{~min}$.

Amplification products were subjected to restriction digestion by the enzyme Fok 1 (Enzynomics, Korea) and Taq 1 (Enzynomics, Korea), respectively. Fragments were separated on $2 \%$ agarose gel, and bands were visualized by ethidium bromide staining under ultraviolet (UV) light. Fok 1 reaction yielded one fragment of $265 \mathrm{bp}$ indicating homozygous wild genotype $(F F)$ (Fig. 1); Taq 1 reaction yielded two fragments of $495 \mathrm{bp}$ and $245 \mathrm{bp}$ indicating a homozygous wild genotype $(F F)$ (Fig. 2).

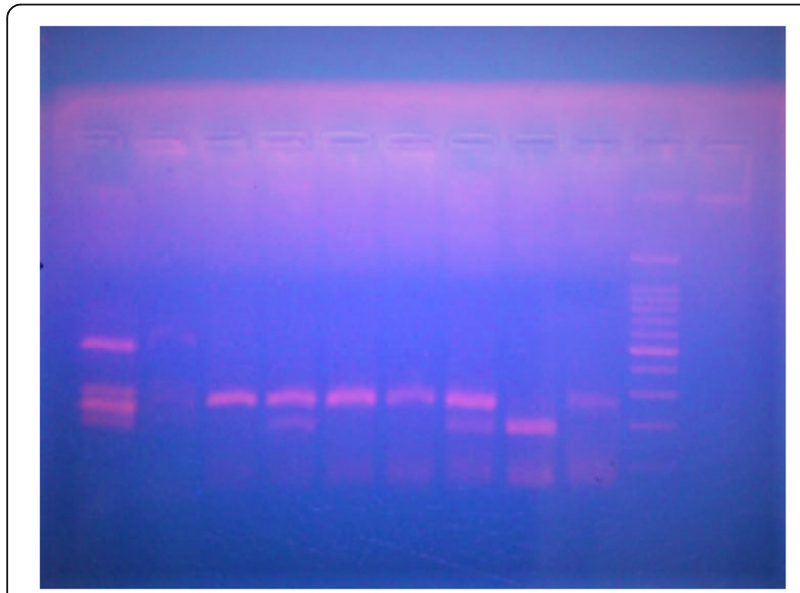

Fig. 1 Vitamin D receptor gene polymorphism (Fok 1). Lanes 1, 3, 4, and 7: homozygous wild FF genotype (265 bp). Lanes 2 and 5: heterozygous genotype Ff (265 bp, $196 \mathrm{bp}$, and $69 \mathrm{bp})$. Lane 6: homozygous mutant ff genotype (196 bp and $69 \mathrm{bp}$ ). Lane 8: 100bp DNA Ladder (100, 200, 300, 400, 500,600,700,800, 900, 1000, 1500 bp)

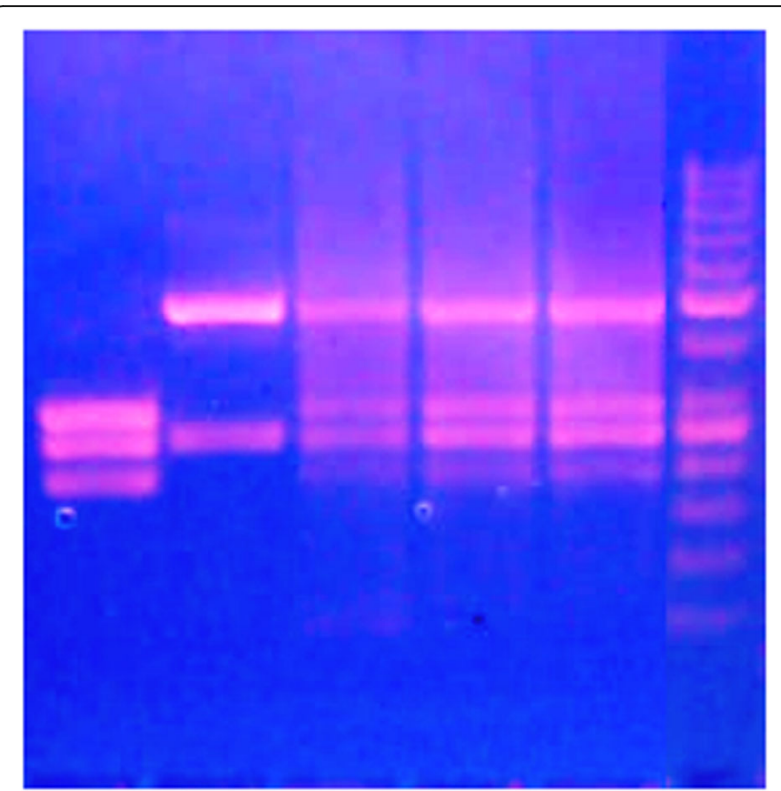

Fig. 2 Vitamin D receptor gene polymorphism (Taq 1). Lane 1: homozygous mutant CC genotype (290bp, 245bp and 205 bp). Lane 2: homozygous wild TT genotype (495 bp and 245bp). Lanes 3,4 and 5: heterozygous genotype TC (495bp, 290bp, 245bp and $205 \mathrm{bp})$. Lane 8: 50 bp DNA Ladder $(50,100,150,200,250,300,400,500,600,700$, $800,900,1000 \mathrm{bp})$

\section{Sample size}

Sample size calculation was performed using the Power and Sample Size Calculation program version 3.0.43. It was based on the following inputs: the power of $90 \%$, type 1 error 0.05 , an equal number of candidates in both cases and controls, true difference in mean between groups 0.9 , and a standard deviation 3.8 . Thirty-eight subjects were found in each group.

\section{Statistical methods}

The data was analyzed using Microsoft Excel 2010 and a statistical package for social science (SPSS version 24.0) for Windows (SPSS IBM., Chicago, IL). Continuous normally distributed variables were presented as mean \pm SD with a $95 \%$ confidence interval using the frequencies and percentage for categorical variables; a $p$ value $<0.05$ was considered statistically significant. To compare the means of normally distributed variables between groups, Student's $t$-test was performed. $\chi^{2}$ test or Fisher's exact test was used to determine the distribution of categorical variables between groups. Haplotype analysis was done using the haplotype analysis software v1.05. The status of Hardy-Weinberg equilibrium (HWE) was checked through the analysis of genotype distribution. Effect modifications were evaluated by stratification; statistical interaction was assessed by including main effect variables and their product 
terms in the multiple stepwise backward logistic regression model.

\section{Results}

\section{Clinical and demographic data}

The study involved 84 preterm neonates, in which 38 patients were diagnosed as BPD and 46 without BPD. The BPD group comprised 16 males (42.1\%) and 22 females (57.9\%); their mean age \pm SD was $30 \pm 1.5$ weeks. While the non-BPD group comprised 24 males $(52.2 \%)$ and 22 females (47.8\%), their mean age \pm SD was $31 \pm$ 1.3 weeks. Among the control group, 32 (69.6\%) cases were less than 30 weeks, while, among the cases, 15 (39.5\%) were less than 30 weeks.

Antenatal variables were comparable between BPD and non-BPD groups with no significant differences, except for gestational age, as the BPD group has significantly lower age. On the other hand, BPD cases required more frequent $\mathrm{O}_{2}$ supply, mechanical ventilation (MV), and inotropic support $(p<0.001)$, and they were admitted for longer periods in comparison to the non-BPD group.

The BPD cases were classified according to the severity of the disease into three groups: mild cases $4(10.6 \%)$, moderate cases 17 (44.7\%), and severe cases 17 (44.7\%). No significant statistical difference in disease severity between BPD cases was found with an age of fewer than 30 weeks versus those aged 30 weeks or more. Among those with 30 or more weeks, three mild, eleven moderate, and nine severe cases were observed versus one mild, six moderate, and eight severe cases in patients less than 30 weeks ( $p$ value 0.642 ).

Hemodynamically, the BPD group showed significant patent ductus arteriosus (PDA) in 23 cases (60.5\%) in comparison to the 11 cases in the non-BPD group (23.9\%) $(p=0.01)$. Regarding the occurrence of neonatal sepsis, late-onset neonatal sepsis was more frequent in the BPD group than the non-BPD group. All demographic and clinical data are shown in Table 1.

\section{Fok 1 and Taq 1 VDR polymorphism results}

The controls and BPD cases fit in the Hardy-Weinberg equilibrium for both Fok1 and Taq1 genotypes and have a $p$ value $>0.05$.

Regarding Fok 1 VDR polymorphism genotypic distribution $(F F, F f, f f)$, no significant statistical difference was detected between the studied groups ( $p$ value $>0.05$ ); homozygous mutant (ff) genotype was the least frequent genotype among BPD and non-BPD groups $(2.6 \%, 13.0 \%$ respectively) ( $p$ value 0.1 ). Moreover, the allelic distributions of $F$ and $f$ alleles did not differ significantly between the cases and the controls ( $p$ value $>0.05$ ).

Regarding Taq 1 genotype distribution, the difference in genotypic distribution (TT, TC, CC) was not statistically significant between the cases and the controls $(p$ value $>0.05)$; the homozygous mutant $(C C)$ genotype frequency was the least frequent genotype in BPD and non-BPD groups (10.5\% and $15.2 \%$ respectively). Furthermore, there was no statistical difference between the allelic distributions ( $T$ allele, $C$ allele) in the studied groups where the mutant $(C)$ allele frequencies were $27 \%$ and $35 \%$ in patients and control groups, respectively, $(p=0.7)$.

Wild genotypes and wild alleles of both Fok 1 and Taq 1 VDR polymorphisms were taken as references for the risk assessment, and analysis revealed no significant association between both polymorphisms and the risk of BPD in our preterm neonates (Table 2). Moreover, no risk association between both polymorphisms and BPD development when cases are more stratified according to gestational age ( $\geq 30$ weeks and $<30$ weeks) (Table 3 ).

Haplotype association analysis revealed no significant differences between the cases and the controls regarding the frequency of different haplotypes (Table 4).

Taq 1 VDR polymorphism was significantly associated with the severity of BPD as the genotypes with mutant allele $\mathrm{C}(C \mathrm{C}+\mathrm{CT})$ were more frequent among severe cases $(52.2 \%)$. But such association was not detected for Fok 1 VDR polymorphism (Table 5).

No associations were detected between Taq 1 and Fok 1 VDR polymorphism genotypes and the disease outcome among preterm newborns (Table 5).

\section{Risk assessment for the development of BPD}

In studying the univariate analysis of potential clinical risk factors for the development of BPD, gestational age, duration of hospitalization, administration of $\mathrm{O}_{2}$, and mechanical ventilation together with inotropes and surfactant had a potential effect on the development of BPD. Moreover, late-onset sepsis, PDA, pneumothorax, IVH, and NEC were associated with an increased risk of BPD (Table 6).

Multiple stepwise backward logistic regression was conducted to find the significant predictors for grouping (control/case). The independent variables entered on step 1 are Taq1, Fok1 VDR gene polymorphisms, gestational age, late-onset neonatal sepsis, PDA, Apgar at 5 min, and RDS grade depending on chest $\mathrm{x}$-ray findings. The model was significant $\mathrm{X} 2(49.27)$ and $p$ value < 0.001 . It can independently explain the change in the grouping by $44.4 \%\left(r^{2} 0.444\right)$. The significant predictors in the model were RDS severity and Apgar at $5 \mathrm{~min}$, which means that an increase in the severity of RDS is more significantly associated with BPD cases than with the controls $(p<0.001$, OR 9.98, 95\% CI 3.2-31.12). Every unit increase in Apgar score at $5 \mathrm{~min}$ increases the probability of the patient not having a disease (control) ( $p$ 0.002 , OR $0.49,95 \%$ CI $0.32-0.77$ ), * $\mathrm{P}$ value $<0.05$ is significant, while **P value $<0.01$ is highly significant. 
Table 1 Demographic and clinical data

\begin{tabular}{|c|c|c|c|}
\hline & Non-BPD, $N=46$ & BPD, $N=38$ & $p$ value \\
\hline Gestational age & $31 \pm 1.3$ & $30 \pm 1.5$ & 0.003 \\
\hline \multicolumn{4}{|l|}{ Gender } \\
\hline Male & $24(52.2 \%)$ & $16(42.1 \%)$ & 0.5 \\
\hline \multicolumn{4}{|l|}{ Mode of delivery } \\
\hline CS & $36(78.3 \%)$ & $30(78.9 \%)$ & 0.9 \\
\hline VD & $10(21.7 \%)$ & $8(21.1 \%)$ & 0.9 \\
\hline Birth weight (g) & $1350.43 \pm 24.66$ & $1298.79 \pm 38.97$ & 0.2 \\
\hline \multicolumn{4}{|l|}{ History of PROM } \\
\hline Yes & $11(23.9 \%)$ & 11 (28.9\%) & 0.7 \\
\hline \multicolumn{4}{|l|}{ Antenatal steroid } \\
\hline Yes & $17(37.0 \%)$ & $13(34.2 \%)$ & 0.8 \\
\hline \multicolumn{4}{|l|}{ Multiple gestation } \\
\hline Yes & $10(21.7 \%)$ & $6(15.8 \%)$ & 0.5 \\
\hline \multicolumn{4}{|l|}{ Preeclampsia } \\
\hline Yes & $6(13 \%)$ & $7(18.4 \%)$ & 0.16 \\
\hline \multicolumn{4}{|l|}{ Duration of admission (days) } \\
\hline Mean \pm SD & $32.67 \pm 1.68$ & $55.21 \pm 2.95$ & 0.001 \\
\hline Duration of $\mathrm{O}_{2}$ (days) & $12.91 \pm 0.93$ & $44.11 \pm 3.0$ & 0.001 \\
\hline \multicolumn{4}{|l|}{ Mechanical ventilation } \\
\hline Yes & $7(15.2 \%)$ & $33(86.8 \%)$ & 0.001 \\
\hline MV duration & $0.46 \pm 0.17$ & $25.63 \pm 2.63$ & 0.001 \\
\hline \multicolumn{4}{|l|}{ Apgar at $1 \mathrm{~min}$} \\
\hline Mean \pm SD & $4.9+1.9$ & $2.6+1.2$ & 0.01 \\
\hline \multicolumn{4}{|l|}{ Apgar at $5 \mathrm{~min}$} \\
\hline Mean \pm SD & $6.7 \pm 1.47$ & $5.2 \pm 1.1$ & 0.01 \\
\hline Inhaled steroid duration (days) & $6.57 \pm 0.89$ & $31.87 \pm 3.35$ & 0.001 \\
\hline \multicolumn{4}{|l|}{ Intake of inotropes } \\
\hline Yes & $18(39.1 \%)$ & $38(100.0 \%)$ & 0.001 \\
\hline Inotropes duration (days) & $2.87 \pm 0.61$ & $16.47 \pm 1.51$ & 0.001 \\
\hline Onset of trophic feeding (days) & $2.35 \pm 0.08$ & $3.29 \pm 0.36$ & 0.01 \\
\hline \multicolumn{4}{|l|}{ TPN } \\
\hline Yes & $43(93.5 \%)$ & $38(100.0 \%)$ & 0.7 \\
\hline Duration of TPN (days) & $13.85 \pm 1.09$ & $31.74 \pm 1.68$ & 0.001 \\
\hline Patent ductus arteriosus & $11(23.9 \%)$ & $23(60.5 \%)$ & 0.001 \\
\hline Early onset sepsis & $19(51.4 \%)$ & $18(48.6 \%)$ & 0.3 \\
\hline Late onset sepsis & $33(47.1 \%)$ & $37(52.9 \%)$ & 0.01 \\
\hline \multicolumn{4}{|l|}{ Admission chest X-ray } \\
\hline Normal & $2(4.3 \%)$ & $0(0.0 \%)$ & 0.2 \\
\hline Mild RDS & $34(73.9 \%)$ & $8(21.1 \%)$ & 0.001 \\
\hline Moderate RDS & $5(10.9 \%)$ & $7(18.4 \%)$ & 0.3 \\
\hline Severe RDS & $5(10.9 \%)$ & $23(60.5 \%)$ & 0.001 \\
\hline \multicolumn{4}{|l|}{ Pneumothorax } \\
\hline Yes & $1(2.2 \%)$ & $25(65.8 \%)$ & 0.001 \\
\hline
\end{tabular}

IVH 
Table 1 Demographic and clinical data (Continued)

\begin{tabular}{|c|c|c|c|}
\hline & Non-BPD, $N=46$ & BPD, $N=38$ & $p$ value \\
\hline Yes & $9(19.6 \%)$ & $23(60.5 \%)$ & 0.001 \\
\hline \multicolumn{4}{|c|}{ Necrotizing enterocolitis } \\
\hline Yes & $6(13.0 \%)$ & 15 (39.5\%) & 0.02 \\
\hline \multicolumn{4}{|l|}{ Jaundice } \\
\hline Yes & $32(69.6 \%)$ & $32(84.2 \%)$ & 0.4 \\
\hline \multicolumn{4}{|c|}{ Intake of surfactant } \\
\hline Yes & $7(15.2 \%)$ & $18(47.4 \%)$ & 0.01 \\
\hline \multicolumn{4}{|l|}{ Outcome } \\
\hline Died & $3(6.5 \%)$ & $12(31.6 \%)$ & 0.01 \\
\hline Living & $43(93.5 \%)$ & $26(68.4 \%)$ & 0.001 \\
\hline
\end{tabular}

$C S$ cesarean section, $V D$ vaginal delivery, $P R O M$ premature rapture of membrane, $M V$ mechanical ventilation, TPN total parenteral nutrition, $R D S$ respiratory distress syndrome, $I V H$, intraventricular hemorrhage

\section{Discussion}

BPD is a relevant chronic lung disease attributed to prematurity. Various studies considered the genetic aberrations involved in the development of BPD and were not conclusive. However, they highlighted several genes, variants, and pathways involved in the susceptibility to BPD [26].

The gene encoding the VDR is placed on chromosome 12; it contains 11 exons and $75 \mathrm{~kb}$ spans of genomic DNA [27]. There are more than two hundred polymorphisms of the VDR gene. The most described were Fok 1, Bsm 1, Apa 1, and Taq 1 polymorphisms. The Fok 1 is in exon 2 and results in the construction of a longer and less active protein, while Bsm1, Apa1, and Taq1 polymorphisms are located between exons 8 and 9 [24].
Taq 1 polymorphism is located at the untranslated region (UTR) of the VDR gene, which has an important role in the regulation of mRNA stability and protein translation, and thus the altered VDR levels may affect vitamin D signaling [28].

The current study revealed that neither Fok 1 nor Taq 1 was associated with susceptibility to BPD in Egyptian neonates. Moreover, the allelic distribution of $F$ and $f$ alleles, on the one hand, and $T$ and $C$ alleles, on the other hand, respectively, was similar in both groups. To the best of our knowledge, Koroglu et al. [29] was the only study that evaluated possible associations of both polymorphisms and BPD. It reported a significant association of mutant Fok1 genotype as a risk factor for the development of BPD (detected in 53.1\% of the cases versus $33.9 \%$ in the control group); furthermore, the mutant

Table 2 Genotypic distribution and allelic frequencies of Taq 1 and Fok 1 VDR polymorphisms

\begin{tabular}{|c|c|c|c|c|c|}
\hline & Non-BPD $(N=46)$, No. $(\%)$ & BPD $(N=38)$, No. $(\%)$ & ${ }^{1} p$ value & Odds ratio & $95 \% \mathrm{Cl}$ \\
\hline \multicolumn{6}{|c|}{ Fok1 VDR gene polymorphism } \\
\hline FF & $26(56.5 \%)$ & $20(52.6 \%)$ & 0.8 & 1 & \\
\hline $\mathrm{Ff}$ & $14(30.4 \%)$ & $17(44.7 \%)$ & 0.3 & 1.579 & $0.631-3.948$ \\
\hline $\mathrm{ff}$ & $6(13.0 \%)$ & $1(2.6 \%)$ & 0.1 & 2.500 & $0.024-1.947$ \\
\hline $\mathrm{Ff}+\mathrm{ff}$ & $20(43.5 \%)$ & $18(47.4 \%)$ & 0.7 & 1.170 & $0.493-2.774$ \\
\hline F allele & $66(71.7 \%)$ & $57(75 \%)$ & 0.8 & 1 & \\
\hline$f$ allele & $26(28.3 \%)$ & $19(25 \%)$ & 0.6 & 0.846 & $0.425-1.686$ \\
\hline \multicolumn{6}{|c|}{ Taq1 VDR gene polymorphism } \\
\hline$\pi$ & $18(39.1 \%)$ & $15(39.5 \%)$ & - & 1 & \\
\hline $\mathrm{TC}$ & $21(45.7 \%)$ & $19(50.0 \%)$ & 0.8 & 1.086 & $0.431-2.737$ \\
\hline CC & $7(15.2 \%)$ & $4(10.5 \%)$ & 0.6 & 0.686 & $0.168-2.799$ \\
\hline $\mathrm{TC}+\mathrm{CC}$ & $28(60.9 \%)$ & $23(60.5 \%)$ & 0.9 & 0.986 & $0.409-2.376$ \\
\hline T allele & $57(62 \%)$ & 49 (64.5\%) & 0 & 1 & \\
\hline C allele & 35 (38\%) & 27 (35\%) & 0.7 & 0.897 & $0.478-1.686$ \\
\hline
\end{tabular}

${ }^{1} p$ value less than 0.05 is statistically significant

$\mathrm{Cl}$ confidence interval 
Table 3 Genotypic distribution of Taq 1 and Fok 1 VDR polymorphisms among different age groups

\begin{tabular}{|c|c|c|c|c|c|}
\hline & Non-BPD (N=14 ), No. (\%) & BPD $(N=23)$, No. $(\%)$ & ${ }^{1} p$ value & Odds ratio & $95 \% \mathrm{Cl}$ \\
\hline \multicolumn{6}{|l|}{ Age $\geq 30$} \\
\hline \multicolumn{6}{|c|}{ Fok1 VDR gene polymorphism } \\
\hline $\mathrm{FF}$ & $7(50 \%)$ & $13(56.5 \%)$ & - & 1 & \\
\hline$F f+f f$ & $7(50 \%)$ & $10(43.5 \%)$ & 0.6997 & 0.769 & $0.202-2.917$ \\
\hline \multicolumn{6}{|c|}{ Taq1 VDR gene polymorphism } \\
\hline TT & $7(50 \%)$ & $9(39.1 \%)$ & - & 1 & \\
\hline \multirow[t]{2}{*}{$\mathrm{TC}+\mathrm{CC}$} & $7(50 \%)$ & $14(60.2 \%)$ & 0.518 & 1.555 & $0.406-5.947$ \\
\hline & Non-BPD $(N=32)$, No. $(\%)$ & BPD $(N=15)$, No. $(\%)$ & ${ }^{1} p$ value & Odds ratio & $95 \% \mathrm{Cl}$ \\
\hline \multicolumn{6}{|l|}{ Age $<30$} \\
\hline \multicolumn{6}{|c|}{ Fok1 VDR gene polymorphism } \\
\hline $\mathrm{FF}$ & 19 (59.4\%) & $7(46.7 \%)$ & - & 1 & \\
\hline$F f+f f$ & $13(40.6 \%)$ & $8(53.3 \%)$ & 0.415 & 1.670 & $0.485-5.746$ \\
\hline \multicolumn{6}{|c|}{ Taq1 VDR gene polymorphism } \\
\hline TT & $11(34.4 \%)$ & $6(40 \%)$ & - & 1 & \\
\hline $\mathrm{TC}+\mathrm{CC}$ & $21(65.5 \%)$ & $9(60 \%)$ & 0.708 & 0.785 & $0.222-2.782$ \\
\hline
\end{tabular}

${ }^{1} p$ value less than 0.05 is statistically significant

$\mathrm{Cl}$ confidence interval

genotype of Taq 1 VDR polymorphism was considered to have a protective effect against BPD (detected in $12.8 \%$ of the cases versus $25.8 \%$ in the control group). However, in their study, after controlling the gestational age and birth weight variables, Fok1 polymorphism did not have a significant effect on BPD susceptibility. Contrary to their results, our study of the Egyptian preterm neonates revealed a low frequency of the mutant genotype of Fok1 (2.6\% in BPD cases, 13\% in non-BPD cases) and mutant genotype of Taq1 polymorphism (10.5\% in BPD cases, $15.2 \%$ in non-BPD cases). These frequencies of different expressions could be attributed to different ethnicity, as was suggested by previous studies [30, 31]. The inconsistencies between studies expressing genetic risks may be due to genetic heterogeneity, gene-toenvironment and/or gene-to-gene interactions, as well as population admixture [32].

The present study revealed that mutant genotypes $(C C+C T)$ of $T a q 1$ VDR polymorphism were significantly more frequent among severe cases of BPD; this finding was not detected for Fok1 polymorphism. Although Taq 1 polymorphism is nonfunctional, it shares

Table 4 Combined Taq1 and Fok1 haplotype frequencies among cases and controls

\begin{tabular}{lllllll}
\hline Haplotype & \multicolumn{2}{l}{ Non-BPD } & & \multicolumn{2}{l}{ BPD } & \multirow{p}{n}{ value } \\
\cline { 2 - 3 } & $\boldsymbol{N}$ & $\%$ & & $\boldsymbol{N}$ & $\%$ & \\
\hline FT & 42 & $45.7 \%$ & & 43 & $56.6 \%$ & 0.3 \\
FC & 15 & $16.3 \%$ & 6 & $7.9 \%$ & 0.1 \\
fT & 24 & $26.1 \%$ & & 14 & $18.4 \%$ & 0.3 \\
fC & 11 & $12.0 \%$ & & 13 & $17.1 \%$ & 0.4 \\
\hline
\end{tabular}

other functional polymorphisms and a complex gene network affecting the expression of the VDR gene, and this could explain its relation to the severity of the disease [28]. Vitamin D and VDR may also play a role in the pathogenesis of chronic lung diseases through epigenetic control of the inflammatory process, immune regulation, and cellular proliferation [12]. Moreover, VDR receptor polymorphism may contribute to a higher incidence of respiratory tract infections through their effects on innate immunity [33]. Alongside all these factors that may explain the link between VDR

Table 5 The association between Taq 1 and Fok 1 VDR polymorphism genotypes and both the outcome and disease severity among BPD cases

\begin{tabular}{lllll}
\hline Variable & & \multicolumn{2}{l}{ Taq1 VDR genotyping } & $p$ value \\
Outcome & TT & TC+CC & \\
\multirow{2}{*}{ Severity of BPD } & Mild & $3(26.7 \%)$ & $8(34.8 \%)$ & 0.6 \\
& Living & $11(73.3 \%)$ & $15(65.2 \%)$ & \\
& Moderate & $7(46.7 \%)$ & $10(43.5 \%)$ & \\
& Severe & $5(33.3 \%)$ & $12(52.2 \%)$ & \\
& & Fok1 VDR genotypes & \\
Outcome & & FF & Ff+ff & \\
& Died & $8(40.0 \%)$ & $4(22.2 \%)$ & 0.1 \\
Severity of BPD & Living & $12(60.0 \%)$ & $14(77.8 \%)$ & \\
& Mild & $1(5.0 \%)$ & $3(16.7 \%)$ & 0.5 \\
& Moderate & $8(40.0 \%)$ & $9(50.0 \%)$ & \\
& Severe & $11(55.0 \%)$ & $6(33.3 \%)$ & \\
\hline
\end{tabular}

$B P D$ bronchopulmonary dysplasia 
Table 6 Univariate analysis of clinical variables influencing the risk of BPD

\begin{tabular}{llll}
\hline Variable & OR & $\mathbf{9 5 \% ~ C l}$ & $\boldsymbol{p}$ value \\
\hline Gestational age & 0.624 & $0.45-0.867$ & $0.005^{* *}$ \\
Sex (male gender) & 0.667 & $0.281-1.584$ & 0.3 \\
Birth weight (g) & 0.999 & $0.997-1.001$ & 0.2 \\
Duration of hospitalization & 1.12 & $1.064-1.18$ & $0.001^{* *}$ \\
Mode of delivery & 0.96 & $0.336-2.739$ & 0.9 \\
Duration $\mathrm{O}_{2}$ & 1.255 & $1.139-1.382$ & $0.001^{* *}$ \\
Mechanical ventilation & 36.771 & $10.665-126.78$ & $0.001^{* *}$ \\
Duration of MV & 1.503 & $1.125-2.009$ & $0.006^{* *}$ \\
Surfactant & 5.014 & $1.797-13.99$ & $0.002^{* *}$ \\
Inhaled steroid duration & 1.277 & $1.143-1.427$ & $0.001^{* *}$ \\
Early onset sepsis & 1.3 & $0.54-3.0$ & 0.6 \\
Late onset sepsis & 14.6 & $1.81-117.6$ & $0.01^{*}$ \\
Patent ductus arteriosus & 4.879 & $1.907-12.48$ & $0.001^{* *}$ \\
Pneumothorax & 86.538 & $10.684-700.97$ & $0.001^{* *}$ \\
Intraventricular hemorrhage & 6.304 & $2.374-16.739$ & $0.001^{* *}$ \\
Necrotizing enterocolitis & 4.348 & $1.481-12.761$ & $0.007^{* *}$ \\
\hline OR odds & & &
\end{tabular}

$O R$ odds ratio, $\mathrm{Cl}$ confidence interval

polymorphism, vitamin $\mathrm{D}$ axis, and severity of BPD, there are several studies that have recognized a relationship between low serum vitamin D level [34], vitamin D binding protein (Gc globulin) [35], and subsequent risk of BPD development.

The current study revealed significant associations between some clinical factors and the risk of BPD, such as lower gestational age, long duration of oxygen therapy, mechanical ventilation, significant PDA, late-onset sepsis, severe RDS, surfactant therapy, and long admission duration. These findings were in agreement with several other studies [29, 36, 37]. Our study also showed that BPD cases were significantly associated with NEC, IVH similarly to Landry et al. [38]. And Mailaparambil et al. [39] concluded that BPD was more associated with some clinical factors rather than genetic polymorphisms.

Moreover, some researchers explored the relationships between Fok 1 and Taq polymorphisms and the development of these BPD-related risk factors in premature babies, as Ustun et al. [40] suggested that Taq1 polymorphism may be considered as a risk factor of RDS, while Mokhtar et al. [41] revealed a significant association of Fok 1 polymorphism and neonatal sepsis whereas Barchitta et al. [42] revealed a significant role of Fok 1 polymorphism with gestational duration and birth weight.

The study limitations here could be attributed to the relatively small sample size enrolled in the study, as well as a single tertiary center experience; thus, further studies with larger cohorts are recommended to confirm the role of these SNPs as molecular incriminators to the addressed pathology. Likewise, $25(\mathrm{OH}) \mathrm{D}$ serum levels should have been examined in order to study the link between the studied genetic polymorphisms and its serum levels.

\section{Conclusion}

Our findings revealed that neither the Fok 1 nor the Taq 1 were associated with an increased risk of BPD. Moreover, the mutant variants of both polymorphisms are detected at a low frequency among Egyptian preterm neonates. The mutant genotypes $(C C+C T)$ of Taq 1 VDR polymorphism were significantly more frequent among severe cases of BPD. Further studies on a larger group of preterm neonates and more genome-wide association studies are required to eradicate the inconsistencies found so far and to elucidate the role of VDR polymorphisms in relation to susceptibility to BPD and its severity.

\section{Abbreviations}

BPD: Bronchopulmonary dysplasia; VDR: Vitamin D receptor; PCR-

RFLP: Polymerase chain reaction-restriction fragment length polymorphism; EOS: Early-onset sepsis; LOS: Late-onset sepsis; NEC: Necrotizing enterocolitis; PDA: Patent ductus arteriosus; IVH: Intraventricular hemorrhage; RDS: Respiratory distress syndrome

\section{Acknowledgements}

We would like to express our gratitude to the Faculty of Medicine, Cairo University, for giving us the chance to accomplish this piece of work with the help of its competent technicians and the updated equipment and instrumentation.

There are no prior publications or submissions with any overlapping information, including studies and patients. No prior publication as an abstract or as an electronic preprint. We have no conflicts of interest to disclose. All authors approved this study.

\section{Reprints}

Nil.

\section{Authors' contributions}

Dr. WA is an assistant professor of Pediatrics at Faculty of Medicine, Cairo University; she is the principal investigator (PI) of the study. Dr. N. AS is a lecturer of Pediatrics at the Faculty of Medicine, Cairo University; she was responsible for writing the manuscript. Dr. AG is an assistant professor of Hematology department at the Faculty of Medicine, Cairo University; she participated in this study by performing the practical part of the study and is the corresponding author. Finally, Dr. R. AW is a lecturer of clinical pathology, Faculty of Medicine, Cairo University; she participated in the statistical analysis. All authors were responsible for selection of the cases, collection of the patient's samples as well as obtaining the informed consent from the chosen cases. They also participated in doing DNA extraction for gene polymorphism, statistical analysis, and result interpretation. Finally, all authors have read and approved the manuscript.

\section{Funding}

This research did not receive any specific grant from funding agencies in the public, commercial, or not-for-profit sectors.

\section{Availability of data and materials}

Nil.

\section{Ethics approval and consent to participate}

An informed written consent was obtained from parents/surrogates of each child before enrollment, and the study was approved by the faculty of medicine (Kasr Alainy Hospitals) ethical committee. All procedures performed in the study involving human participants were in accordance with the ethical standards of the faculty's ethical research committee and with the 
1964 Helsinki Declaration and its later amendments or comparable ethical standards. Reference number: N/A

\section{Consent for publication}

An informed consent was obtained from all individual participants included in this study.

\section{Competing interests}

The authors declare no competing interests.

\section{Author details}

'Department of Pediatrics, Faculty of Medicine, Cairo University, Cairo, Egypt. ${ }^{2}$ Department of Clinical and Chemical Pathology, Cairo University, Cairo, Egypt. ${ }^{3}$ Cairo, Egypt.

\section{Received: 24 September 2020 Accepted: 15 February 2021} Published online: 09 April 2021

\section{References}

1. Mahlman M, Karjalainen MK, Huusko JM, Andersson S, Kari MA, Tammela OK et al (2017) Genome-wide association study of bronchopulmonary dysplasia: a potential role for variants near the CRP gene. Sci Rep 7(1):9271

2. Stoll BJ, Hansen NI, Bell EF, Walsh MC, Carlo WA, Shankaran S et al (2015) Trends in care practices, morbidity, and mortality of extremely preterm neonates 1993-2012. JAMA 314(10):1039-1051

3. Stoll BJ, Hansen NI, Bell EF, Shankaran S, Laptook AR, Walsh MC et al (2010) Neonatal outcomes of extremely preterm infants from the NICHD Neonatal Research Network. Pediatrics 126(3):443-456

4. Balany J, Bhandari V (2015) Understanding the impact of infection, inflammation, and their persistence in the pathogenesis of bronchopulmonary dysplasia. Front Med 2:90

5. Jobe AH (2016) Mechanisms of lung injury and bronchopulmonary dysplasia. Am J Perinatol 33(11):1076-1078

6. Bhandari V, Bizzarro MJ, Shetty A, Zhong X, Page GP, Zhang H et al (2006) Familial and genetic susceptibility to major neonatal morbidities in preterm twins. Pediatrics 117(6):1901-1906

7. Lavoie PM, Pham C, Jang KL (2008) Heritability of bronchopulmonary dysplasia defined according to the consensus statement of the National Institute of Health. Pediatrics 122(3):479-485

8. Jain D, Bancalari E (2014) Bronchopulmonary dysplasia: clinical perspective. Birth Defects Res A Clin Mol Teratol 100(3):134-144

9. Misra M, Pacaud D, Petryk A, Collett-Solberg PF, Kappy M (2008) Vitamin D deficiency in children and its management: review of current knowledge and recommendations. Pediatrics 122(2):398-417

10. White $\mathrm{JH}$ (2008) Vitamin D signaling, infectious diseases and regulation of innate immunity. Infect Immun 76(9):3837-3843

11. Valdivielso JM, Fernandez E (2006) Vitamin D receptor polymorphisms and diseases. Clin Chim Acta 371(1-2):1-2

12. Sundar IK, Rahman I (2011) Vitamin D and susceptibility of chronic lung diseases: role of epigenetics. Front Pharmacol 2:50

13. Sakurai R, Shin E, Fonseca S, Sakurai T, Litonjua AA, Weiss ST et al (2009) 1a, $25(\mathrm{OH}) 2 \mathrm{D} 3$ and its 3-epimer promote rat lung alveolar epithelialmesenchymal interactions and inhibit lipofibroblast apoptosis. Am J Physiol Lung Cell Mol Physiol 297(3):496-505

14. Mandell E, Seedorf G, Gien J, Abman SH (2014) Vitamin D treatment improves survival and infant lung structure after intra-amniotic endotoxin exposure in rats: potential role for the prevention of bronchopulmonary dysplasia. Am J Physiol Lung Cell Mol Physiol 306(5):L420-L428

15. Mandell E, Seedorf GJ, Ryan S, Gien J, Cramer SD, Abman SH (2015) Antenatal endotoxin disrupts lung vitamin D receptor and 25hydroxyvitamin D 1a-hydroxylase expression in the developing rat. Am J Physiol Lung Cell Mol Physiol 309(9):L1018-L1026

16. Saadoon A, Ambalavanan N, Zinn K, Ashraf AP, MacEwen M, Nicola T, Fanucchi MV, Harris WT (2017) Effect of prenatal versus postnatal vitamin D deficiency on pulmonary structure and function in mice. Am J Respir Cell Mol Biol 56(3):383-392

17. Rehan VK, Torday JS, Peleg S, Gennaro L, Vouros P, Padbury J, Rao DS, Reddy GS (2002) 1a, 25-Dihydroxy-3-epi-vitamin D3, a natural metabolite of 1a, 25-dihydroxy vitamin D3: production and biological activity studies in pulmonary alveolar type II cells. Mol Genet Metab 76(1):46-56
18. Edelson JD, Chan S, Jassal D, Post M, Tanswell AK (1994) Vitamin D stimulates DNA synthesis in alveolar type-II cells. BiochimBiophys Acta 1221(2):159-166

19. Jobe AH, Bancalari E (2001) Bronchopulmonary dysplasia. Am J Respir Crit Care Med 163(7):1723-1729

20. Sweet DG, Carnielli V, Greisen G, Hallman M, Ozek E, Plavka R et al (2013) European consensus guidelines on the management of neonatal respiratory distress syndrome in preterm infants-2013 update. Neonatology. 103(4):353-368

21. M Paetzel. Respiratory distress syndrome (grade 1-4) of the premature and newborn (IRDS). Ped Rad [serial online] 2, 11. URL: www.PedRad.info/?sea rch=20021110223558 Accessed 29 Nov 2020

22. Stoll BJ, Hansen NI, Sánchez PJ, Faix RG, Poindexter BB, Van Meurs KP et al (2011) Early onset neonatal sepsis: the burden of group B streptococcal and E. coli disease continues. Pediatrics. 127(5):817-826

23. Bell MJ, Ternberg JL, Feigin RD, Keating JP, Marshall RI, Barton LE et al (1978) Neonatal necrotizing enterocolitis. Therapeutic decisions based upon clinical staging. Ann Surg 187(1):1

24. Ames SK, Ellis KJ, Gunn SK, Copeland KC, Abrams SA (1999) Vitamin D receptor gene Fok1 polymorphism predicts calcium absorption and bone mineral density in children. J Bone Miner Res 14(5):740-746

25. Dasgupta S, Dutta J, Annamaneni S, Kudugunti N, Battini MR (2015) Association of vitamin D receptor gene polymorphisms with polycystic ovary syndrome among Indian women. Indian J Med Res 142(3):276

26. Yu KH, Li J, Snyder M, Shaw GM, O'Brodovich HM (2016) The genetic predisposition to bronchopulmonary dysplasia. Curr Opin Pediatr 28(3): 318-323

27. Taymans SE, Pack S, Pak E, Orban Z, Barsony J, Zhuang Z et al (1999) The human vitamin $D$ receptor gene (VDR) is localized to region 12cen-q12 by fluorescent in-situ hybridization and radiation hybrid mapping: genetic and physical VDR Map. J Bone Miner Res 14(7):1163-1166

28. Uitterlinden AG, Fang Y, van Meurs JB, Pols HA, van Leeuwen JP (2004) Genetics and biology of vitamin D receptor polymorphisms. Gene 338(2): 143-156

29. Koroglu OA, Onay H, Cakmak B, Bilgin B, Yalaz M, Tunc S et al (2014) Association of vitamin $D$ receptor gene polymorphisms and bronchopulmonary dysplasia. Pediatr Res 76(2):171-176

30. Pei FH, Wang YJ, Gao SL, Liu BR, Du YJ, Liu W et al (2011) Vitamin D receptor gene polymorphism and ulcerative colitis susceptibility in Han Chinese. J Dig Dis 12(2):90-98

31. O Neill V, Asani FF, Jeffery TJ, Saccone DS, Bornman L (2013) Vitamin D receptor gene expression and function in a South African population: ethnicity, vitamin D and Fokl. PLoS One 8(6):e67663

32. Gennari L, Merlotti D, De Paola V, Calabro A, Becherini L, Martini G et al (2005) Estrogen receptor gene polymorphisms and the genetics of osteoporosis: a HuGE review. Am J Epidemiol 161(4):307-320

33. Roth $D E$, Jones $A B$, Prosser $C$, Robinson JL, Vohra $S$ (2008) Vitamin D receptor polymorphisms and the risk of acute lower respiratory tract infection in early childhood. J Infect Dis 197:676-680

34. Mao X, Qiu J, Zhao L, Xu J, Yin J, Yang Y, Zhang M, Cheng R (2018) Vitamin $D$ and IL-10 deficiency in preterm neonates with bronchopulmonary dysplasia. Front Pediatr 6:246

35. Pehlevan OS, Karatekin G, Koksal V, Benzer D, Gursoy T, Yavuz T, Ovali F (2015) Association of vitamin D binding protein polymorphisms with bronchopulmonary dysplasia: a case-control study of gc globulin and bronchopulmonary dysplasia. J Perinatol 35(9):763-767

36. Collaborative Study Group for Bronchopulmonary Dysplasia of Prematurity in China (2011) Incidence and risk factors of bronchopulmonary dysplasia in premature infants in 10 hospitals in China. Zhonghua Er Ke Za Zhi 49(9): 655-662

37. Elhawary NA, Tayeb MT, Abdel-Ghafar S, Rashad M, Alkhotani AA (2013) TNF-238 polymorphism may predict bronchopulmonary dysplasia among preterm infants in the Egyptian population. Pediatr Pulmonol 48(7):699-706

38. Landry JS, Menzies D (2011) Occurrence and severity of bronchopulmonary dysplasia and respiratory distress syndrome after a preterm birth. Paediatr Child Health 16(7):399-403

39. Mailaparambil B, Krueger M, Heizmann U, Schlegel K, Heinze J, Heinzmann A (2010) Genetic and epidemiological risk factors in the development of bronchopulmonary dysplasia. Dis Markers 29(1):1-9

40. Ustun N, Eyerci N, Karadag N, Yesilyurt A, Zenciroglu A, Okumus N (2019) Association of vitamin D receptor gene Fokl and Taql polymorphisms and risk of RDS. J Matern Fetal Neonatal Med 27:1-7 
41. Mokhtar WA, Mohamed AF, Allam RM, Zidan NI, Mokhtar GA, Malek MM et al (2018) Vitamin D deficiency and vitamin D receptor gene polymorphisms as a risk factor for severe early-onset neonatal sepsis. Alex J Pediatr 31(2):82-90

42. Barchitta M, Maugeri A, La Rosa M, Magnano San Lio R, Favara G, Panella M et al (2018) Single nucleotide polymorphisms in vitamin D receptor gene affect birth weight and the risk of preterm birth: results from the "mamma \& bambino" cohort and a meta-analysis. Nutrients 10(9):1172

\section{Publisher's Note}

Springer Nature remains neutral with regard to jurisdictional claims in published maps and institutional affiliations.

\section{Submit your manuscript to a SpringerOpen ${ }^{\circ}$ journal and benefit from:}

- Convenient online submission

- Rigorous peer review

- Open access: articles freely available online

High visibility within the field

- Retaining the copyright to your article

Submit your next manuscript at $\boldsymbol{\nabla}$ springeropen.com 